J. Amer. Soc. Hort. ScI. 126(3):364-370. 2001.

\title{
Can We Approach Complete Dependence on Foliar- applied Urea Nitrogen in an Early-maturing Peach?
}

\author{
R. Scott Johnson ${ }^{1}$ \\ Department of Pomology, University of California Kearney Agricultural Center, 9240 S. Riverbend \\ Avenue, Parlier, CA 93648 \\ Rich Rosecrance \\ College of Agriculture, California State University, Chico, CA 95929 \\ Steve Weinbaum \\ Department of Pomology, University of California, Davis, CA 95616 \\ Harry Andris \\ Cooperative Extension Service, 1720 S. Maple Avenue, Fresno, CA 93702 \\ Jinzheng Wang \\ Shandong Pomology Institute, Longtan Road 64, Taian, Shandong 27100, People's Republic of China
}

AdDitional INDEX words. Prunus persica, nitrate leaching, low biuret urea, fruit weight, fruit yield, vegetative growth

\begin{abstract}
Aвstract. The suspected contributory role of soil fertilization to nitrate pollution of groundwater has encouraged exploration of novel fertilizer management strategies. Foliar-applied urea has long been used to supplement soil $\mathbf{N}$ applications, but there have been no apparent attempts to replace soil $\mathrm{N}$ applications completely in deciduous orchard culture. Two experiments were conducted to study the effect of foliar-applied low biuret urea on productivity and fruit growth of the early maturing peach [Prunus persica L. Batsch (Peach Group)] cultivar, Early Maycrest. In a 3-year experiment, a total foliar urea regime was compared to an equivalent amount of $\mathrm{N}$ applied to the soil. The foliar treatment supplied adequate amounts of $\mathrm{N}$ to the various organs of the tree including the roots, shoots, and fruit buds, but mean fruit weights were lower than in the soil-fertilized treatment. In a 2-year experiment, a 50\%-50\% combination treatment of soil-applied $\mathrm{N}$ in late summer with foliar-applied $\mathrm{N}$ in October, maintained yields and fruit weight equal to the soilfertilized control. Some soil-applied $\mathbf{N}$ appears necessary for optimum fruit growth. Soil $\mathbf{N}$ application may be needed to support root proliferation and associated processes, but we did not determine a threshold amount of soil-applied $\mathbf{N}$ needed. The combination treatment also reduced excessive vegetative growth which is characteristic of early maturing peach cultivars. Therefore, this combination treatment offers promise as a viable commercial practice for maintaining tree productivity and controlling excessive vegetative growth in peach trees.
\end{abstract}

Urea can be absorbed rapidly and efficiently by the leaves of most crop plants (Gooding and Davies, 1992; Reickenberg and Pritts, 1996; Sanchez et al., 1990; Shim et al., 1972; Swietlik and Faust, 1984 ). In contrast to early reports on peaches [Prunus persica (Peach Group)] (Norton and Childers, 1954; Weinburger, 1949), recent studies have shown foliar urea uptake efficiencies of $48 \%$ to $69 \%$ and translocation of the foliar applied urea $\mathrm{N}$ to all organs of the tree including the roots (Rosecrance et al., 1998a, 1998b; Tagliavini et al., 1998). Thus, foliar fertilization may improve $\mathrm{N}$ use efficiency relative to soil applied $\mathrm{N}$ and help reduce leaching of nitrates into the groundwater (Embleton et al., 1986).

Past work has largely concentrated on rates of low biuret $(<0.25 \%$ biuret) urea which do not cause obvious phytotoxic symptoms ( $0.5 \%$ to $1.0 \%$ urea) (Fisher et al., 1948; Forshey, 1963; Weinberger, 1949). However, numerous sprays would be required to meet total plant $\mathrm{N}$ need using these concentrations, (Reickenberg and Pritts, 1996; Weinbaum, 1988) and multiple applications would not be cost effective. Higher (5\% to $10 \%$ urea)

Received for publication 10 Apr. 2000. Accepted for publication 19 Dec. 2000 This research was supported, in part, by the Fertilizer Research and Education Program of California Department of Food and Agriculture. The cost of publishing this paper was defrayed in part by the payment of page charges. Under postal regulations, this paper therefore must be hereby marked advertisement solely to indicate this fact.

${ }^{1}$ Corresponding author; e-mail: sjohnson@uckac.edu. foliar urea application rates may be more feasible in deciduous orchards if used later in the season prior to leaf senescence. At that time, leaf phytotoxicity is of less concern since leaf senescence is imminent, and the fruit have already been harvested. This strategy substantially increases $\mathrm{N}$ reserves in apples [Malus sylvestris (L.) Mill. var. domestica (Borkh.) Mansf.] (Han et al., 1989; Oland, 1960), peaches (Rosecrance et al., 1998b) and pears (Pyrus communis L.) (Sanchez et al., 1990) and improves flowering, fruit set, and shoot growth (Han et al., 1989; Khemira et al., 1998; Shim et al., 1972). Foliar uptake of urea and transport of urea $\mathrm{N}$ is efficient as long as the treatment is made before the onset of leaf senescence (Rosecrance et al., 1998b). Urea has also been shown to improve the uptake of micronutrients (El-Fouly et al., 1990) which could make this an even more appealing practice to fruit growers. Peach growers in California routinely apply zinc foliar sprays in the fall (Johnson and Uriu, 1989).

Late season foliar urea applications to fruit trees may raise several concerns. First, since urea and ammonia (the first breakdown product of urea) are known to be toxic to plants (Krogmeier et al., 1989; Romero-Aranda and Syvertsen, 1996), deleterious effects on reproductive and vegetative meristems may accompany urea spray applications. Even very low rates of urea $(0.2 \%)$ affect tomato (Lycopersicon esculentum Mill.) seedling growth adversely (Nicoulaud and Bloom, 1996). If $\mathrm{N}$ is supplied through the aboveground organs (thus bypassing the roots), is root growth and function negatively impacted? Will uptake of other nutrients 
be affected, leading to a nutrient imbalance or deficiency? Will root-produced hormones such as cytokinins be affected and influence growth elsewhere in the tree? In short, will the physiological processes affecting tree growth and productivity continue normally under a foliar fertilization program?

This study was initiated to address some of the aforementioned questions using an early season peach cultivar. Our objective was to determine whether foliar-applied urea $\mathrm{N}$ could completely replace soil-applied $\mathrm{N}$ fertilization without detrimental effects. Vegetative growth, crop yield, mean fruit weight, tissue $\mathrm{N}$ concentrations during dormancy, and leaf nutrient concentrations were monitored.

\section{Materials and Methods}

A block of 'Early Maycrest' peaches on 'Nemaguard' peach rootstock planted in 1988 at the Kearney Agricultural Center, Parlier, California (lat. $36.6^{\circ} \mathrm{N}$, long. $119.5^{\circ} \mathrm{W}$ ) was used for both experiments. Soil type was a Hanford sandy loam (typic xerothents), and standard furrow irrigation and pest management practices were used.

EXPERIMENT 1. COMPARISON OF FOLIAR N vS. SOIL N APPLICATIONS. Trees were planted at a $5.5 \times 5.5 \mathrm{~m}$ spacing and trained to an open vase system. Four replications of three nitrogen fertilization treatments with three adjacent trees per plot were imposed in Sept. 1993 as follows: 1) nonfertilized control, 2) soil fertilized treatment, and 3) foliar urea treatment.

Treatment 2 consisted of $\mathrm{N}$ at $112 \mathrm{~kg} \cdot \mathrm{ha}^{-1}$ as ammonium nitrate buried in a shallow trench $(2 \mathrm{~m}$ long $\times 15 \mathrm{~cm}$ deep $)$ on both sides of each tree and followed immediately with rain or irrigation. In 1993 and 1994, all the fertilizer was applied in early to mid September. In the third year, half was applied in Sept. 1995 and half in mid Apr. 1996 about 6 weeks after full bloom and 1 month before harvest. Treatment 3 received foliar treatments of low biuret urea in early to mid October. Each application consisted of a $4.3 \%(\mathrm{w} / \mathrm{v})$ urea $(46 \% \mathrm{~N})$ solution applied at a rate of about 2800 $\mathrm{L} \cdot \mathrm{ha}^{-1}$ by handgun for a total $\mathrm{N}$ of $56 \mathrm{~kg} \cdot \mathrm{ha}^{-1}$. Since the literature suggested foliar urea is not taken up efficiently by peach leaves, three applications spaced 2 weeks apart were made in 1993 resulting in a total $\mathrm{N}$ application of $168 \mathrm{~kg} \cdot \mathrm{ha}^{-1}$. Once it was clear that ample $\mathrm{N}$ was being taken up, this treatment was reduced to two foliar applications in Oct. 1994 and 1995. Thus, the same amounts of $\mathrm{N}\left(112 \mathrm{~kg} \cdot \mathrm{ha}^{-1}\right)$ were applied foliarly or to the soil in 1994 and 1995.

EXPERIMENT 2. COMPARISON OF SOIL/FOLIAR N COMBINATIONS VS. SOIL N APPLICATION. Trees were planted at a $2.0 \times 5.5 \mathrm{~m}$ spacing and trained to a perpendicular "V" system (DeJong et al., 1994). Starting in the Spring 1995, five replications of four treatments with two adjacent trees per plot were imposed as follows: 1$)$ nonfertilized control, 2) soil $\mathrm{N}$ only ( $\mathrm{N}$ at $56 \mathrm{~kg} \cdot \mathrm{ha}^{-1}$ in April and $56 \mathrm{~kg} \cdot \mathrm{ha}^{-1}$ in September), 3) combination 1 (N at $56 \mathrm{~kg} \cdot \mathrm{ha}^{-1}$ in April and $56 \mathrm{~kg} \cdot \mathrm{ha}^{-1}$ as foliar urea in October), and 4) combination 2 ( $\mathrm{N}$ at $56 \mathrm{~kg} \cdot \mathrm{ha}^{-1}$ in September and $56 \mathrm{~kg} \cdot \mathrm{ha}^{-1}$ as foliar urea in October).

As in Expt. 1, soil-applied $\mathrm{N}$ was buried in a shallow trench (1 $\mathrm{m}$ long $\times 15 \mathrm{~cm}$ deep) on both sides of each tree. Calcium nitrate was used in April and ammonium nitrate in September. Foliar treatments consisted of a single spray of a $4.3 \%(\mathrm{w} / \mathrm{v})$ solution of low biuret urea at $2800 \mathrm{~L} \cdot \mathrm{ha}^{-1}$ applied in mid October.

The following data were collected in each experiment: Yield per tree was measured at each of two harvests as the fruit reached commercial maturity in mid May. Total fruit counts were taken and average fruit weight calculated. Summer pruning was carried out in July or August of each year and consisted primarily of water sprout removal in the center of the trees. Summer pruning occurred early in the morning and fresh weight (FW) measurements were taken immediately. At the time of commercial thinning in late March or early April of each year, thinned fruitlets were collected. Samples of 100 to 200 fruit per tree were weighed and average fruit FW calculated. Trees were thinned to leave 300 to 350 fruit per tree in Expt. 1 and 100 to 150 fruit per tree in Expt. 2. During the winter of 1995-96, flower buds were collected on several occasions. Bud scales were removed from a 100 to 200 bud sample per tree. Each sample was then dried at $65^{\circ} \mathrm{C}$ for 48 to $96 \mathrm{~h}$, weighed, ground, and sent to the University of California (UC) Davis analytical lab for standard N analysis.

Nitrogen analysis was also carried out on dormant (December or January) 1-year-old shoots 20 to $40 \mathrm{~cm}$ in length and roots 5 to $10 \mathrm{~mm}$ in diameter sampled from the top $30 \mathrm{~cm}$ of soil within 1 $\mathrm{m}$ of the trunk at the same time as the shoot samples. Midshoot leaves were collected during the standard sampling period of June and July and were analyzed by the UC analytical lab for N, P, K, $\mathrm{Ca}, \mathrm{Mg}, \mathrm{Zn}$, and $\mathrm{Mn}$. Leaf samples were also collected frequently in the fall during the period of foliar urea applications and natural senescence and were analyzed for N. All leaf samples were washed in a detergent solution and double rinsed in deionized water to remove surface dust and residual urea.

Standard analysis of variance procedures were used with comparisons among treatment means performed with Duncan's multiple range test at $P \leq 0.05$.

\section{Results and Discussion}

Exclusive reliance on foliar-applied $\mathrm{N}$ resulted in yields comparable to the soil-fertilized treatment (Table 1); however, average fruit weight in foliar-treated trees was significantly smaller in 1994 and 1995 and showed a similar trend in 1996. This occurred despite the fact that $\mathrm{N}$ was supplied to dormant shoots, roots, and buds by the foliar treatment (Table 2). Exclusive reliance on foliar-applied $\mathrm{N}$ resulted in root $\mathrm{N}$ concentrations which were greater than those in the nonfertilized control and equal to those in the soil-fertilized treatment in all three years. Shoot $\mathrm{N}$ concentration responded similarly to foliar-applied urea except it was less than the soil-fertilized treatment in 1 of 3 years. Flower bud $\mathrm{N}$ concentration was generally greater in the foliar urea treatment than either of the other two treatments during the winter of 199596 (Table 2). These results suggest that $\mathrm{N}$ did not limit fruit growth directly in trees fertilized foliarly. Instead, it was hypothesized that some $\mathrm{N}$ may be necessary in the soil around the roots to stimulate processes such as root proliferation (Robinson, 1996) or cytokinin production (Horgan and Wareing, 1980; Kuiper et al., 1989; Salama and Wareing, 1979; Skene, 1975). The combination treatments of Expt. 2 were initiated to test this hypothesis.

In Expt. 2, all three of the fertilizer treatments stimulated greater yields and fruit weight than the nonfertilized control in both 1996 and 1997 (Table 3). The 50\% foliar N/50\% soil N combination treatments were just as effective as the $100 \%$ soil $\mathrm{N}$ treatment at maintaining yield and average fruit weight, especially combination 2 which combined a September soil N application with an October foliar $\mathrm{N}$ application. We suspect a reduction in root proliferation when $\mathrm{N}$ was applied exclusively via the foliage, but no measurements were taken. Additional research is needed to verify this hypothesis and to determine how much the soil $\mathrm{N}$ application could be further reduced from the $56 \mathrm{~kg} \cdot \mathrm{ha}^{-1}$ 
used in this experiment (and redirected foliarly) without reducing fruit weight.

Alternatively, complete reliance on foliar-applied urea fertilization, may reduce the uptake of other mineral nutrients, thus leading to deficiencies. For instance, decreasing the level of nitrate nutrition to tomato plants decreased cation uptake (Kirkby and Knight, 1977). Also, soil nitrate favors uptake of cations compared to ammonium nutrition (Kirkby, 1968). Therefore, one might expect lower cation concentrations following foliar urea treatments, but this was generally not the case. For Expt. 1, mid summer leaf concentrations of the major cations did not differ among treatments (Table 2). Only the leaf concentration of Mn was affected by the treatments, but none were below the minimum sufficiency level. There were a few differences among treatments in Expt. 2 (Table 4), and whenever significant differences occurred, the combination 2 treatment was never lower than the soil-fertilized control. As with Expt. 1, Mn seemed to be the nutrient most affected by the treatments.

One possible explanation of these differences in leaf $\mathrm{Mn}$ is the effect soil fertilization may have had on Mn availability through changing soil $\mathrm{pH}$. The soil fertilizer controls of both experiments and combination 2 of Expt. 2 all received an ammonium based fertilizer (ammonium nitrate) which may have lowered soil $\mathrm{pH}$ and made Mn more available. Even though Mn levels were generally low, they were never below $20 \mathrm{mg} \cdot \mathrm{kg}^{-1}$, which is considered deficient for peaches in California (Johnson and Uriu,

Table 1.Effects of soil or foliar fertilizer treatments on yield parameters and vegetative growth of 'Early Maycrest' peach. Soil fertilized treatment received N at $112 \mathrm{~kg} \cdot \mathrm{ha}^{-1}$ applied in September $(1993,1994)$ or half in September (1995) and half in April (1996). Foliar urea treatment received three (1993) or two $(1994,1995)$ applications of $\mathrm{N}$ at $56 \mathrm{~kg} \cdot \mathrm{ha}^{-1}$ applied as foliar urea in October, spaced 2 weeks apart.

\begin{tabular}{|c|c|c|c|}
\hline \multirow[b]{2}{*}{ Parameter } & \multicolumn{3}{|c|}{ Fertilizer treatment } \\
\hline & $\begin{array}{l}\text { Nonfertilized } \\
\text { control }\end{array}$ & $\begin{array}{c}\text { Soil } \\
\text { fertilized }\end{array}$ & $\begin{array}{c}\text { Foliar } \\
\text { urea }\end{array}$ \\
\hline \multicolumn{4}{|l|}{ Yield (kg/tree) } \\
\hline May 1994 & 39.7 & 36.5 & 37.7 \\
\hline May 1995 & $22.3 b^{z}$ & $36.4 \mathrm{a}$ & $30.9 \mathrm{a}$ \\
\hline May 1996 & 27.0 & 36.3 & 31.5 \\
\hline \multicolumn{4}{|l|}{ Fruit load (no./tree) } \\
\hline May 1994 & 393 & 306 & 343 \\
\hline May 1995 & $253 \mathrm{~b}$ & $337 \mathrm{a}$ & $334 \mathrm{a}$ \\
\hline May 1996 & 272 & 320 & 291 \\
\hline \multicolumn{4}{|l|}{ Fruit wt (g/fruit) } \\
\hline May 1994 & $102.7 \mathrm{c}$ & $117.5 \mathrm{a}$ & $110.2 \mathrm{~b}$ \\
\hline May 1995 & $87.8 \mathrm{~b}$ & $108.6 \mathrm{a}$ & $92.1 \mathrm{~b}$ \\
\hline May 1996 & $99.2 \mathrm{~b}$ & $113.5 \mathrm{a}$ & $108.7 \mathrm{a}$ \\
\hline \multicolumn{4}{|c|}{ Summer pruning wt $(\mathrm{kg} / \mathrm{tree})$} \\
\hline July 1994 & $4.3 \mathrm{~b}$ & $8.9 \mathrm{a}$ & $9.7 \mathrm{a}$ \\
\hline July 1995 & $2.5 \mathrm{~b}$ & $5.5 \mathrm{a}$ & $5.3 \mathrm{a}$ \\
\hline July 1996 & $3.7 \mathrm{c}$ & $10.0 \mathrm{a}$ & $6.8 \mathrm{~b}$ \\
\hline \multicolumn{4}{|c|}{ Flower bud wt (mg dry wt/bud) } \\
\hline Dec. 1995 & $0.31 \mathrm{~b}$ & $0.34 \mathrm{a}$ & $0.29 \mathrm{~b}$ \\
\hline Jan. 1996 & $0.60 \mathrm{~b}$ & $0.69 \mathrm{a}$ & $0.51 \mathrm{c}$ \\
\hline Feb. 1996 & $1.25 \mathrm{~b}$ & $1.89 \mathrm{a}$ & $1.30 \mathrm{~b}$ \\
\hline \multicolumn{4}{|c|}{ Thinning fruitlet wt (g/fruit) } \\
\hline 30 Mar. 1995 & $0.58 \mathrm{c}$ & $0.84 \mathrm{a}$ & $0.68 \mathrm{~b}$ \\
\hline 8 Apr. 1996 & $1.74 \mathrm{c}$ & $2.75 \mathrm{a}$ & $2.17 \mathrm{~b}$ \\
\hline
\end{tabular}

1989). Leaf Mn concentrations correlated very well with fruit weight in each of the 5 years of both experiments ( $r$ values ranged from 0.88 to 0.99 for individual years). Since slight Mn deficiency has been shown to substantially reduce fruit weight (Val et al., 1997), future research is needed to determine the role of $\mathrm{Mn}$ in fruit growth or whether it is an indicator of some other physiological process affected by fertilization method.

Further research is needed to test the different hypotheses. If root growth and cytokinin production is the limiting factor, perhaps other mineral nutrients could be used to stimulate root growth or foliar cytokinin sprays could be used to overcome the

Table 2. Effects of soil or foliar fertilizer treatments on shoot, root, and bud $\mathrm{N}$ concentrations during dormancy and July leaf N, P, K, Ca, Mg, $\mathrm{Zn}$, and Mn concentrations of 'Early Maycrest' peach. See Table 1 for treatment details.

\begin{tabular}{|c|c|c|c|}
\hline \multirow[b]{2}{*}{ Parameter } & \multicolumn{3}{|c|}{ Fertilizer treatment } \\
\hline & $\begin{array}{c}\text { Nonfertilized } \\
\text { control }\end{array}$ & $\begin{array}{c}\text { Soil } \\
\text { fertilized }\end{array}$ & $\begin{array}{c}\text { Foliar } \\
\text { urea }\end{array}$ \\
\hline \multicolumn{4}{|c|}{$\overline{\text { Shoot N }\left(\mathrm{mg} \cdot \mathrm{g}^{-1}\right)}$} \\
\hline Jan. 1994 & $13.1 \mathrm{~b}^{\mathrm{z}}$ & $17.6 \mathrm{a}$ & $17.6 \mathrm{a}$ \\
\hline Dec. 1994 & $10.5 \mathrm{c}$ & $16.0 \mathrm{a}$ & $13.4 \mathrm{~b}$ \\
\hline Jan. 1996 & $10.1 \mathrm{~b}$ & $13.3 \mathrm{a}$ & $13.0 \mathrm{a}$ \\
\hline \multicolumn{4}{|l|}{ Root N (mg. $\left.\mathrm{g}^{-1}\right)$} \\
\hline Jan. 1994 & $7.8 \mathrm{~b}$ & $16.1 \mathrm{a}$ & $15.8 \mathrm{a}$ \\
\hline Dec. 1994 & $6.3 \mathrm{~b}$ & $12.7 \mathrm{a}$ & $12.9 \mathrm{a}$ \\
\hline Jan. 1996 & $7.3 \mathrm{~b}$ & $16.6 \mathrm{a}$ & $13.8 \mathrm{a}$ \\
\hline \multicolumn{4}{|l|}{$\operatorname{Bud~N}\left(\mathrm{mg} \cdot \mathrm{g}^{-1}\right)$} \\
\hline Dec. 1995 & $44.2 \mathrm{c}$ & $47.3 \mathrm{~b}$ & $52.7 \mathrm{a}$ \\
\hline Jan. 1996 & $45.2 \mathrm{c}$ & $50.2 \mathrm{~b}$ & $52.9 \mathrm{a}$ \\
\hline Feb. 1996 & $44.0 \mathrm{~b}$ & $49.7 \mathrm{a}$ & $51.6 \mathrm{a}$ \\
\hline \multicolumn{4}{|l|}{ Leaf $\mathrm{N}\left(\mathrm{mg} \cdot \mathrm{g}^{-1}\right)$} \\
\hline July 1994 & $25.9 \mathrm{~b}$ & $26.9 \mathrm{~b}$ & $29.9 \mathrm{a}$ \\
\hline July 1995 & 24.6 & 26.0 & 25.4 \\
\hline July 1996 & $25.6 \mathrm{~b}$ & $28.9 \mathrm{a}$ & $26.9 \mathrm{~b}$ \\
\hline \multicolumn{4}{|l|}{ Leaf $\mathrm{P}\left(\mathrm{mg} \cdot \mathrm{g}^{-1}\right)$} \\
\hline July 1994 & $4.6 \mathrm{a}$ & $2.8 \mathrm{~b}$ & $2.8 \mathrm{~b}$ \\
\hline July 1995 & $3.9 \mathrm{a}$ & $2.1 \mathrm{~b}$ & $2.4 \mathrm{~b}$ \\
\hline July 1996 & $3.8 \mathrm{a}$ & $2.0 \mathrm{~b}$ & $2.3 \mathrm{~b}$ \\
\hline \multicolumn{4}{|l|}{ Leaf $K\left(\mathrm{mg} \cdot \mathrm{g}^{-1}\right)$} \\
\hline July 1994 & 31.0 & 30.2 & 32.1 \\
\hline July 1995 & 28.7 & 28.9 & 30.0 \\
\hline July 1996 & 27.1 & 26.9 & 28.0 \\
\hline \multicolumn{4}{|c|}{ Leaf $\mathrm{Ca}\left(\mathrm{mg} \cdot \mathrm{g}^{-1}\right)$} \\
\hline July 1994 & 19.3 & 18.3 & 16.6 \\
\hline July 1995 & 30.6 & 39.7 & 34.2 \\
\hline July 1996 & 20.2 & 21.1 & 19.9 \\
\hline \multicolumn{4}{|c|}{ Leaf $\mathrm{Mg}\left(\mathrm{mg} \cdot \mathrm{g}^{-1}\right)$} \\
\hline July 1994 & 5.8 & 5.4 & 5.2 \\
\hline July 1995 & 6.5 & 6.1 & 6.0 \\
\hline July 1996 & 6.0 & 5.6 & 6.0 \\
\hline \multicolumn{4}{|c|}{ Leaf $\mathrm{Zn}\left(\mathrm{mg} \cdot \mathrm{kg}^{-1}\right)$} \\
\hline July 1994 & 12.5 & 13.3 & 16.0 \\
\hline July 1995 & 15.5 & 17.3 & 15.5 \\
\hline July 1996 & 16.3 & 15.8 & 15.3 \\
\hline \multicolumn{4}{|c|}{ Leaf Mn $\left(\mathrm{mg} \cdot \mathrm{kg}^{-1}\right)$} \\
\hline July 1994 & $24.5 \mathrm{~b}$ & $32.5 \mathrm{a}$ & $26.5 \mathrm{~b}$ \\
\hline July 1995 & $26.3 \mathrm{c}$ & $57.3 \mathrm{a}$ & $30.3 \mathrm{~b}$ \\
\hline July 1996 & $21.8 \mathrm{c}$ & $48.0 \mathrm{a}$ & $27.8 \mathrm{~b}$ \\
\hline
\end{tabular}

${ }_{\mathrm{z}}$ Mean separation within rows by Duncan's multiple range test, $P \leq 0.05$. Rows with no letters indicate no significant differences. 
Table 3. Effects of soil or soil/foliar fertilizer combination treatments on yield parameters and vegetative growth of 'Early Maycrest' peach. Soil fertilized treatment received $\mathrm{N}$ at $112 \mathrm{~kg} \cdot \mathrm{ha}^{-1}$, half in April and half in September. Combination 1 also received $112 \mathrm{~kg} \cdot \mathrm{ha}^{-1}$, half to the soil in April and half to the foliage in October. Combination 2 was identical to combination 1 except the soil application was made in September instead of April.

\begin{tabular}{|c|c|c|c|c|}
\hline \multirow[b]{2}{*}{ Parameter } & \multicolumn{4}{|c|}{ Fertilizer treatment } \\
\hline & $\begin{array}{l}\text { Nonfertilized } \\
\text { control }\end{array}$ & $\begin{array}{c}\text { Soil } \\
\text { fertilized }\end{array}$ & $\begin{array}{l}\text { Soil-foliar } \\
\text { combination } 1\end{array}$ & $\begin{array}{c}\text { Soil-foliar } \\
\text { combination } 2\end{array}$ \\
\hline \multicolumn{5}{|l|}{ Yield (kg/tree) } \\
\hline May 1996 & $8.4 b^{z}$ & $12.8 \mathrm{a}$ & $10.7 \mathrm{ab}$ & $12.6 \mathrm{a}$ \\
\hline May 1997 & $10.7 \mathrm{~b}$ & $15.0 \mathrm{a}$ & $15.1 \mathrm{a}$ & $15.1 \mathrm{a}$ \\
\hline \multicolumn{5}{|c|}{ Fruit load (no./tree) } \\
\hline May 1996 & 86 & 112 & 97 & 111 \\
\hline May 1997 & 117 & 136 & 148 & 136 \\
\hline \multicolumn{5}{|c|}{ Fruit wt (g/fruit) } \\
\hline May 1996 & $97.7 \mathrm{~b}$ & $114.8 \mathrm{a}$ & $110.3 \mathrm{a}$ & $113.5 \mathrm{a}$ \\
\hline May 1997 & $90.9 \mathrm{~b}$ & $110.8 \mathrm{a}$ & $103.1 \mathrm{a}$ & $110.9 \mathrm{a}$ \\
\hline \multicolumn{5}{|c|}{ Summer pruning wt (kg/tree) } \\
\hline July 1996 & $2.4 \mathrm{~b}$ & $5.9 \mathrm{a}$ & $5.0 \mathrm{a}$ & $3.5 \mathrm{~b}$ \\
\hline Aug. 1997 & $3.2 \mathrm{c}$ & $9.0 \mathrm{a}$ & $6.6 \mathrm{~b}$ & $6.2 \mathrm{~b}$ \\
\hline \multicolumn{5}{|c|}{ Flower bud wt (mg dry wt/bud) } \\
\hline Dec. 1995 & $0.34 \mathrm{~b}$ & $0.36 \mathrm{ab}$ & $0.34 \mathrm{~b}$ & $0.37 \mathrm{a}$ \\
\hline Jan. 1996 & $0.73 \mathrm{~b}$ & $0.78 \mathrm{ab}$ & $0.72 \mathrm{~b}$ & $0.81 \mathrm{a}$ \\
\hline \multicolumn{5}{|c|}{ Thinning fruitlet wt (g/fruit) } \\
\hline Apr. 1996 & $1.7 \mathrm{c}$ & $2.5 \mathrm{a}$ & $2.1 \mathrm{~b}$ & $2.7 \mathrm{a}$ \\
\hline Apr. 1997 & $2.0 \mathrm{c}$ & $2.6 \mathrm{ab}$ & $2.4 \mathrm{~b}$ & $2.8 \mathrm{a}$ \\
\hline
\end{tabular}

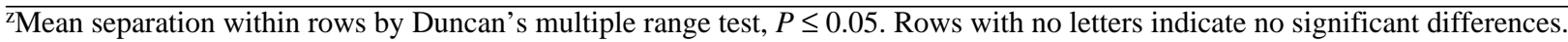

effect on fruit growth. Alternatively, root growth might be stimulated by using lower soil $\mathrm{N}$ application rates than those used in these experiments, enabling foliar application of $>50 \%$ of the annual $\mathrm{N}$ demand. Likewise, if $\mathrm{Mn}$ is the limiting factor for fruit growth, it would be quite easy to supplement it foliarly.

The soil/foliar combination treatments (especially combination 2) offered additional horticultural advantages including reduced vegetative growth as measured by summer pruning weights (Table 3). For early maturing cultivars such as 'Early Maycrest', substantial shoot growth after harvest must be pruned out to maintain fruitfulness in the more shaded parts of tree canopies. Some reduction in this vegetative growth is beneficial to the long-term productivity of the tree as long as yields and fruit weight are not decreased (as happened to the nonfertilized control). Renewal of fruiting wood was sufficient in the combination treatments to maintain productivity.

$\mathrm{N}$ concentrations varied among treatments in both dormant tissues and midsummer leaf samples (Table 4), and reflected the timing of $\mathrm{N}$ applications. For instance, combination 2 trees which received all their $\mathrm{N}$ in late summer and fall, had the highest $\mathrm{N}$ concentrations in dormant shoots and roots but tended to have the lowest midsummer leaf $\mathrm{N}$ concentrations. On the other hand, combination 1 trees received half their $\mathrm{N}$ in the spring and thus had higher summer leaf $\mathrm{N}$ concentrations but lower $\mathrm{N}$ concentrations in roots and shoots during dormancy. These contrasting patterns might help explain the subtle differences observed in fruit and shoot growth between the two combination treatments. Combination 2 was associated with the highest $\mathrm{N}$ concentration in dormant tissues, and presumably the greatest availability of $\mathrm{N}$ for flowering and early fruit and shoot growth. Therefore, combination 2 tended to support the greatest weight per fruit (Table 3 ). After harvest, the leaf $\mathrm{N}$ concentration decreased in combination 2 trees, leading to a cessation of shoot elongation and an overall reduction in vegetative growth (Table 3 ). These data suggest that foliar-applied urea may help fine tune $\mathrm{N}$ availability in the tree, providing maximum availability in the spring for early fruit growth but minimizing it later in the season resulting in earlier shoot growth cessation.

The foliar urea treatments sharply increased leaf $\mathrm{N}$ concentrations the day after urea application in October (Figs. 1 and 2). Leaf $\mathrm{N}$ concentrations then declined over the next week or two. At the time of the second foliar spray in Expt. 1, the trees were already $60 \%$ defoliated which may have limited the effectiveness of that application (Fig. 1). However, in Expt. 2, where only one foliar application was made, leaf $\mathrm{N}$ concentrations declined to near prespray levels within a week and before extensive defoliation had occurred, indicating much of the applied $\mathrm{N}$ was quickly transported out of the leaves and into the rest of the plant. The combination 2 treatment was particularly effective since the September soil fertilization increased leaf $\mathrm{N}$ level and delayed defoliation (Fig. 2). Rapid movement of foliar-applied urea N out of leaves has been reported when applied just prior to natural leaf senescence (Rosecrance et al., 1998b).

It should be noted, however, that leaf $\mathrm{N}$ of the foliar urea treatments did not decrease to the same level as the nonsprayed treatments at senescence (Figs. 1 and 2). This suggests the trees were not as efficient at remobilizing their own leaf $\mathrm{N}$ when sprayed with urea. Possible explanations include the following: First, the concentration of urea used in this experiment $(4.3 \%)$, may have resulted in urea or ammonia toxicity which inhibited normal leaf $\mathrm{N}$ resorption. Marginal leaf burn was obvious within several days after spraying. Second, transport of foliar-applied N within the tree may be partially controlled by the $\mathrm{N}$ status of the tree (Lea-Cox and Syvertsen, 1995). Therefore, once the tree has taken up a substantial amount of $\mathrm{N}$ from the urea spray, its demand for additional $\mathrm{N}$ may be reduced significantly. Other studies using 4\% urea solutions applied to apple trees in the fall have reported mixed results. In one experiment, leaf $\mathrm{N}$ concentra- 
Table 4. Effects of soil or soil/foliar fertilizer combination treatments on shoot, root and bud $\mathrm{N}$ concentration during dormancy and leaf $\mathrm{P}$, $\mathrm{K}$, Ca, $\mathrm{Mg}, \mathrm{Zn}$, and Mn concentrations of 'Early Maycrest' peach. See Table 3 for treatment details.

\begin{tabular}{|c|c|c|c|c|}
\hline \multirow[b]{2}{*}{ Parameter } & \multicolumn{4}{|c|}{ Fertilizer treatment } \\
\hline & $\begin{array}{l}\text { Nonfertilized } \\
\text { control }\end{array}$ & $\begin{array}{c}\text { Soil } \\
\text { fertilized }\end{array}$ & $\begin{array}{c}\text { Soil-foliar } \\
\text { combination } 1\end{array}$ & $\begin{array}{c}\text { Soil-foliar } \\
\text { combination } 2\end{array}$ \\
\hline \multicolumn{5}{|c|}{ Shoot N $\left(\mathrm{mg} \cdot \mathrm{g}^{-1}\right)$} \\
\hline Jan. 1996 & $10.2 \mathrm{~d}^{\mathrm{z}}$ & $12.8 \mathrm{~b}$ & $11.6 \mathrm{c}$ & $14.0 \mathrm{a}$ \\
\hline Jan. 1997 & $10.4 \mathrm{~b}$ & $12.7 \mathrm{a}$ & $10.7 \mathrm{~b}$ & $12.5 \mathrm{a}$ \\
\hline \multicolumn{5}{|l|}{ Root N $\left(\mathrm{mg} \cdot \mathrm{g}^{-1}\right)$} \\
\hline Jan. 1996 & $7.0 \mathrm{~d}$ & $13.3 \mathrm{~b}$ & $9.7 \mathrm{c}$ & $15.9 \mathrm{a}$ \\
\hline Jan. 1997 & $10.2 \mathrm{c}$ & $12.9 \mathrm{~b}$ & $13.7 \mathrm{~b}$ & $16.2 \mathrm{a}$ \\
\hline \multicolumn{5}{|l|}{$\operatorname{Bud} N\left(\mathrm{mg} \cdot \mathrm{g}^{-1}\right)$} \\
\hline Dec. 1995 & $44.9 \mathrm{c}$ & $45.9 \mathrm{c}$ & $47.6 \mathrm{~b}$ & $49.5 \mathrm{a}$ \\
\hline Jan. 1996 & $48.2 \mathrm{~b}$ & $53.9 \mathrm{a}$ & $52.1 \mathrm{a}$ & $53.8 \mathrm{a}$ \\
\hline \multicolumn{5}{|l|}{ Leaf $\mathrm{N}\left(\mathrm{mg} \cdot \mathrm{g}^{-1}\right)$} \\
\hline July 1996 & $24.5 \mathrm{~b}$ & $27.6 \mathrm{a}$ & $27.9 \mathrm{a}$ & $26.0 \mathrm{ab}$ \\
\hline July 1997 & $25.6 \mathrm{~b}$ & $27.2 \mathrm{ab}$ & $29.2 \mathrm{a}$ & $26.3 \mathrm{~b}$ \\
\hline \multicolumn{5}{|l|}{ Leaf $\mathrm{P}\left(\mathrm{mg} \cdot \mathrm{g}^{-1}\right)$} \\
\hline July 1996 & $4.6 \mathrm{a}$ & $2.1 \mathrm{~b}$ & $2.0 \mathrm{~b}$ & $2.3 \mathrm{~b}$ \\
\hline July 1997 & $4.5 \mathrm{a}$ & $2.0 \mathrm{c}$ & $2.2 \mathrm{c}$ & $3.2 \mathrm{~b}$ \\
\hline \multicolumn{5}{|c|}{ Leaf $\mathrm{K}\left(\mathrm{mg} \cdot \mathrm{g}^{-1}\right)$} \\
\hline July 1996 & 30.0 & 27.6 & 29.3 & 30.5 \\
\hline July 1997 & 31.8 & 30.6 & 31.7 & 33.5 \\
\hline \multicolumn{5}{|c|}{ Leaf Ca $\left(\mathrm{mg} \cdot \mathrm{g}^{-1}\right)$} \\
\hline July 1996 & 19.7 & 20.0 & 19.5 & 19.8 \\
\hline July 1997 & 25.9 & 27.7 & 26.4 & 27.7 \\
\hline \multicolumn{5}{|c|}{ Leaf $\mathrm{Mg}\left(\mathrm{mg} \cdot \mathrm{g}^{-1}\right)$} \\
\hline July 1996 & 5.9 & 5.9 & 6.0 & 6.0 \\
\hline July 1997 & $6.1 \mathrm{~b}$ & $6.2 \mathrm{~b}$ & $6.4 \mathrm{~b}$ & $6.9 \mathrm{a}$ \\
\hline \multicolumn{5}{|c|}{ Leaf Zn $\left(\mathrm{mg} \cdot \mathrm{kg}^{-1}\right)$} \\
\hline July 1996 & $14.2 \mathrm{c}$ & $19.8 \mathrm{a}$ & $16.4 b c$ & $18.2 \mathrm{ab}$ \\
\hline July 1997 & $12.4 \mathrm{~b}$ & $13.4 \mathrm{ab}$ & $14.0 \mathrm{ab}$ & $14.4 \mathrm{a}$ \\
\hline \multicolumn{5}{|c|}{ Leaf $\mathrm{Mn}\left(\mathrm{mg} \cdot \mathrm{kg}^{-1}\right)$} \\
\hline July 1996 & $24.4 \mathrm{c}$ & $35.4 \mathrm{a}$ & $27.8 \mathrm{~b}$ & $35.4 \mathrm{a}$ \\
\hline July 1997 & $22.8 \mathrm{c}$ & $33.4 \mathrm{a}$ & $28.2 \mathrm{~b}$ & $33.6 \mathrm{a}$ \\
\hline
\end{tabular}

${ }^{\bar{z}}$ Mean separation within rows by Duncan's multiple range test, $P \leq 0.05$. Rows with no letters indicate no significant differences.

tion was increased by foliar-applied urea but, by the time of leaf abscission, was equivalent to leaves on nontreated trees of both high and low N status (Delap, 1967). In another study, results similar to ours were reported but the time of urea application (September vs. October) also made a difference (Oland, 1963) in 1 year. Additional research is needed to determine how tree $\mathrm{N}$ status, time of application, and urea concentration may be manipulated to optimize $\mathrm{N}$ utilization of both the applied urea and existing leaf $\mathrm{N}$.

One appealing aspect of foliar urea applications is the potential for increased fertilizer $\mathrm{N}$ recovery. Quantification of this parameter by applying labeled $\mathrm{N}$ and excavating whole trees has shown soil-applied $\mathrm{N}$ recoveries to range from $8 \%$ (Sanchez et al., 1991) to as high as $57 \%$ (Feigenbaum et al., 1987). This

Fig. 1. (A) Leaf $\mathrm{N}$ concentration and (B) percentage defoliation resulting from soil and foliar fertilizer treatments to 'Early Maycrest' peach trees during Fall 1995 (Expt. 1). Arrows indicate time of foliar urea applications. high recovery, however, was achieved under conditions of high $\mathrm{N}$ starvation and, in the same experiment $40 \%$ was a more typical $\mathrm{N}$ recovery percentage. In general, well managed and optimally fertilized trees reportedly recover $35 \%$ to $50 \%$ of the labelled $\mathrm{N}$

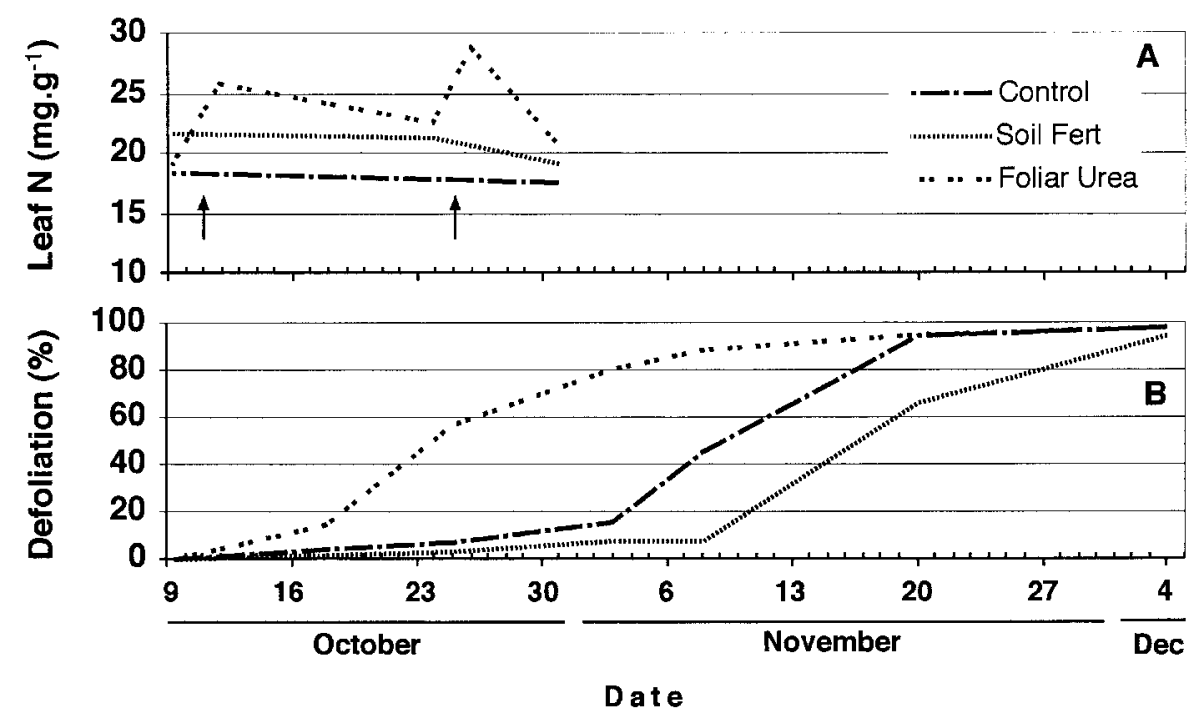



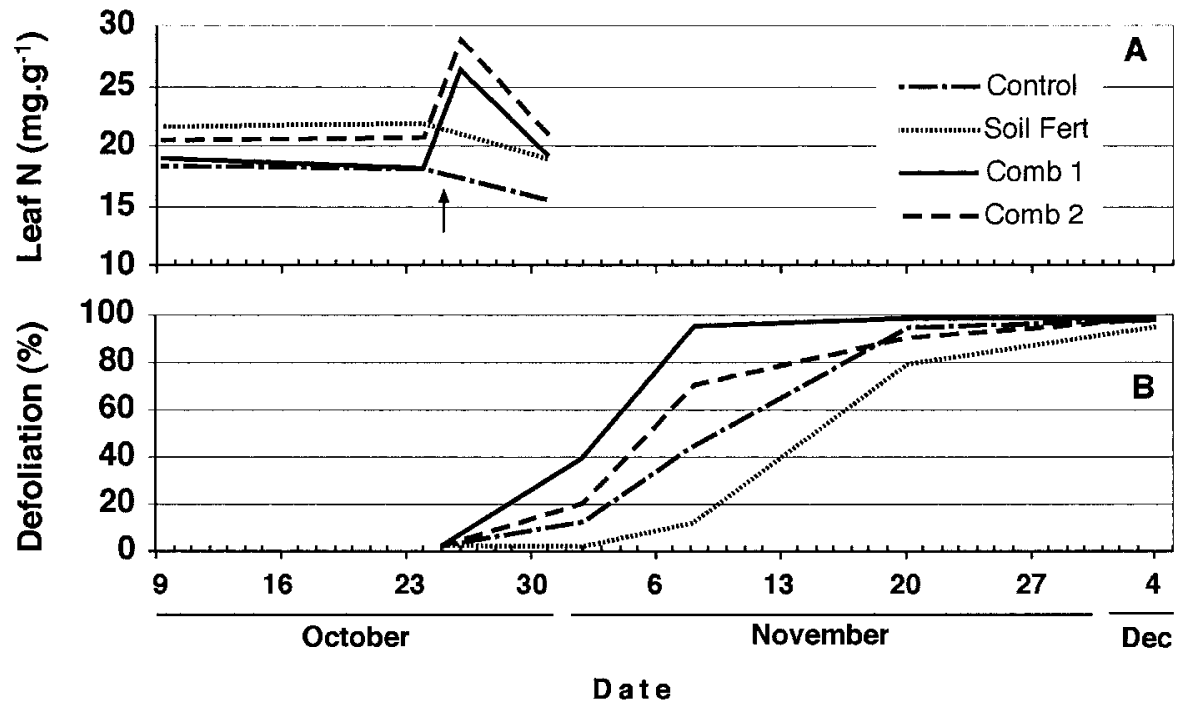

Fig. 2. (A) Leaf N concentration and (B) percentage defoliation resulting from soil and foliar fertilizer treatments to 'Early Maycrest' peach trees during the fall of 1995 (Expt. 2). Arrow indicates time of foliar urea application.

applied to the soil (Ledgard and Smith, 1992; Weinbaum et al, 1994; Weinbaum and Van Kessel, 1998). Higher recovery rates, between $50 \%$ and $70 \%$, are typical of foliar-applied urea $\mathrm{N}$ studies (Rosecrance et al., 1998b; Tagliavini et al., 1998). Studies where soil and foliar $\mathrm{N}$ applications were compared by applying equal amounts of $\mathrm{N}$ have indicated greater $\mathrm{N}$ recovery following foliar treatment. Often leaf $\mathrm{N}$ and fruit $\mathrm{N}$ concentrations were higher and sometimes yields were increased with foliar treatments (Leece and Dirou, 1979; Marks and Clarke, 1995). Embleton and Jones (1974) concluded from 56 experiment years of citrus (Citrus L. sp.) data that foliar-applied $\mathrm{N}$ was as effective as soilapplied $\mathrm{N}$ for fruit production. Twelve years later, after several additional studies, Embleton et al. (1986) resolved that the best fertilizer treatment was a combination of foliar urea and soil applied N, similar to our findings in this experiment. In their studies, the combination treatments reduced leaching of fertilizer-derived $\mathrm{N}$ and subsequent groundwater pollution while maintaining productivity and fruit quality. Therefore, there is fairly consistent evidence to suggest equal or greater $\mathrm{N}$ recovery and less environmental pollution by substituting at least part of the soil-applied fertilizer with foliar urea. It is not yet clear how much $\mathrm{N}$ can be applied foliarly or how little soil $\mathrm{N}$ is needed to maintain tree productivity and fruit size.

In summary, a regime of total foliar urea to an early maturing peach cultivar reduced weight per fruit significantly and exhibited a tendency to reduce tree yield compared to the soil fertilized treatment. However, a combination treatment of soil fertilization in late summer and foliar urea in October maintained productivity and fruit weight comparable to the total soil-applied treatment over a 2-year period. In addition, this combination treatment provided the additional horticultural benefit of reducing vegetative growth. Therefore, it appears to show promise as a viable commercial cultural practice.

\section{Literature Cited}

DeJong, T.M., K.R. Day, J.F. Doyle, and R.S. Johnson. 1994. The Kearney Agricultural Center perpendicular "V" (KAC-V) for peaches and nectarines. HortTechnology 4:362-367.
Delap, A.V. 1967. The response of young apple trees of differing nitrogen status to a urea spray in autumn. Rpt. E. Malling Res. Sta. 1966.

El-Fouly, M.M., A.F.A. Fawzi, Z.M. Mobarak, E.A. Aly, and F.E. Abdalla. 1990. Micronutrient foliar intake by different crop plants, as affected by accompanying urea, p. 267-273. In: M.L. van Beusichem (ed.). Plant nutrition: Physiology and application. Kluwer Academic Publishers, Boston.

Embleton, T.W. and W.W. Jones. 1974. Foliarapplied nitrogen for citrus fertilization. J. Environ. Quality 3:388-391.

Embleton, T.W., M. Matsumura, L.H. Stolzy, D.A. Devitt, W.W. Jones, R. El-Motaium, and L.L. Summers. 1986. Citrus nitrogen fertilizer management, groundwater pollution, soil salinity and nitrogen balance. Appl. Agr. Res. 1:57-64.

Feigenbaum, S., H. Bielorai, Y. Erner, and S. Dasberg. 1987. The fate of ${ }^{15} \mathrm{~N}$ labeled nitrogen applied to mature citrus trees. Plant and Soil 97:179-187.

Fisher, E., D. Boynton, and K. Skodvin. 1948. Nitrogen fertilization of the 'McIntosh' apple with leaf sprays of urea. Proc. Amer. Soc. Hort. Sci. 51:23-32.

Forshey, C.G. 1963. A comparison of soil nitrogen fertilization and urea sprays as sources of nitrogen for apple trees in sand culture. Proc. Amer. Soc. Hort. Sci. 83:32-45.

Gooding, M.J. and W.P. Davies. 1992. Foliar urea fertilization of cereals: A review. Fert. Res. 32:209-222.

Han, Z., X. Zeng, and F. Wang. 1989. Effects of autumn foliar applications of ${ }^{15} \mathrm{~N}$-urea on nitrogen storage and reuse in apple. J. Plant Nutr. 12:675-685.

Horgan, J.M. and P.F. Wareing. 1980. Cytokinins and the growth responses of seedlings of Betula pendula Roth. and Acerpseudoplatanus L. to nitrogen and phosphorus deficiency. J. Expt. Bot. 31:525-532.

Johnson, R.S. and K. Uriu. 1989. Mineral nutrition, p. 68-91. In: J.H. LaRue and R.S. Johnson (eds.). Peaches, plums, nectarines: Growing and handling for fresh market. Univ. of Calif. Press, Oakland.

Khemira, H., A.N. Azarenko, D. Sugar, and T.L. Righetti. 1998. Postharvest nitrogen application effect on ovule longevity of 'Comice' pear trees. J. Plant Nutr. 21:405-411.

Kirkby, E.A. 1968. Influence of ammonium and nitrate nutrition on the cation-anion balance and nitrogen and carbohydrate metabolism of white mustard plants grown in dilute nutrient solutions. Soil Sci. 105:133-141.

Kirkby, E.A. and A.H. Knight. 1977. Influence of the level of nitrate nutrition on ion uptake and assimilation, organic acid accumulation, and cation-anion balance in whole tomato plants. Plant Physiol. 60:349-353.

Krogmeier, M.J., G.W. McCarty, and J.M. Bremner. 1989. Phytotoxicity of foliar-applied urea. Proc. Natl. Acad. Sci. USA 86:8189-8191. Kuiper, D., J. Schuit, and P.J.C. Kuiper. 1989. Effects of internal and external cytokinin concentrations on root growth and shoot to root ratio of Plantago major spp. pleiosperma at different nutrient conditions, $\mathrm{p}$. 183-188. In: B.C. Loughman, O. Gasparikova, and J. Kolek (eds.). Structural and functional aspects of transport in roots. Kluwer Academic Publishers, Boston.

Lea-Cox, J.D. and J.P. Syvertsen. 1995. Nitrogen uptake by citrus leaves. J. Amer. Soc. Hort. Sci. 120:505-509.

Ledgard, S.F. and G.S. Smith. 1992. Fate of ${ }^{15} \mathrm{~N}$-labelled nitrogen fertilizer applied to kiwifruit (Actinidia deliciosa) vines. II. Temporal changes in ${ }^{15} \mathrm{~N}$ within vines. Plant and Soil 147:59-68.

Leece, D.R. and J.F. Dirou. 1979. Comparison of urea foliar sprays containing hydrocarbon or silicone surfactants with soil-applied nitrogen in maintaining the leaf nitrogen concentration of prune trees. J. Amer. Soc. Hort. Sci. 104:644-648. 
Marks, M.J. and A. Clarke. 1995. The response of 'Bramley's' seedling apple trees to soil and foliar applied nitrogen. Acta Hort. 383:421-428.

Nicoulaud, B.A.L. and A.J. Bloom. 1996. Absorption and assimilation of foliarly applied urea in tomato. J. Amer. Soc. Hort. Sci. 121:11171121.

Norton, R.A. and N.F. Childers. 1954. Experiments with urea sprays on the peach. Proc. Amer. Soc. Hort. Sci. 63:23-31.

Oland, K. 1960. Nitrogen feeding of apple trees by postharvest urea sprays. Nature 185:857.

Oland, K. 1963. Responses of cropping apple trees to postharvest urea sprays. Nature 198:1282-1283.

Reikenberg, R.L. and M.P. Pritts. 1996. Dynamics of nutrient uptake from foliar fertilizers in red raspberry (Rubus idaeus L.). J. Amer. Soc. Hort. Sci. 121:158-163.

Robinson, D. 1996. Resource captive by localized root proliferation: Why do plants bother? Ann. Bot. 77:179-185.

Romero-Aranda, R. and J.P. Syvertsen. 1996. The influence of foliarapplied urea nitrogen and saline solutions on net gas exchange of Citrus leaves. J. Amer. Soc. Hort. Sci. 121:501-506.

Rosecrance, R.C., R.S. Johnson, and S.A. Weinbaum. 1998a. Foliar uptake of urea-N by nectarine leaves: A reassessment. HortScience 33:158.

Rosecrance, R.C., R.S. Johnson, and S.A. Weinbaum. 1998b. The effect of timing of post-harvest foliar urea sprays on nitrogen absorption and partitioning in peach and nectarine trees. J. Hort. Sci. Biotechnol. 73:856-861.

Salama, A.M., S. El-D.A., and P.F. Wareing. 1979. Effects of mineral nutrition on endogenous cytokinins in plants of sunflower (Helianthus annuus L.). J. Expt. Bot. 30:971-981.

Sanchez, E.E., T.L. Righetti, D. Sugar, and P.B. Lombard. 1990. Response of 'Comice' pear tree to a postharvest urea spray. J. Hort. Sci.
65:541-546.

Sanchez, E.E., T.L. Righetti, D. Sugar, and P.B. Lombard. 1991. Recycling of nitrogen in field-grown 'Comice' pears. J. Hort. Sci. 66:479486.

Shim, K., J.S. Titus, and W.E. Splittstoesser. 1972. The utilization of postharvest urea sprays by senescing apple leaves. J. Amer. Soc. Hort. Sci. 97:592-596.

Skene, K.G.M. 1975. Cytokinin production by roots as a factor in the control of plant growth, p. 365-396. In: J.G. Torrey and D.T. Clarkson (eds.). The development and function of roots. Academic Press, London/New York.

Swietlik, D. and M. Faust. 1984. Foliar nutrition of fruit crops. Hort. Rev. 6:287-355.

Tagliavini, M., P. Millard, and M. Quartieri. 1998. Storage of foliarabsorbed nitrogen and remobilization for spring growth in young nectarine (Prunus persica var. nectarina) trees. Tree Physiol. 18:203207

Val, J., E. Monge, L. Montañés, and M. Sanz. 1997. Manganese deficiency in peach trees: Prognosis and fruit quality. Acta Hort. 448:345-50.

Weinbaum, S.A. 1988. Foliar nutrition of fruit trees, p. 81-100. In: P.M. Neumann (ed.). Plant growth and leaf-applied chemicals. CRC Press, Inc., Boca Raton, Fla.

Weinbaum, S.A., G.A. Picchioni, T.T. Muraoka, L. Ferguson, and P.H. Brown. 1994. Fertilizer nitrogen and boron uptake, storage, and allocation vary during the alternate-bearing cycle in pistachio trees. J. Amer. Soc. Hort. Sci. 119:24-31.

Weinbaum, S.A. and C. Van Kessel. 1998. Quantitative estimates of uptake and internal cycling of ${ }^{15} \mathrm{~N}$-labeled fertilizer in mature walnut trees. Tree Physiol. 18:795-801.

Weinberger, J.H. 1949. Tests on foliar fertilization of peach trees with urea. Proc. Amer. Soc. Hort. Sci. 53:26-28. 